DOI https://doi.org/10.18551/rjoas.2017-11.57

\title{
STUDY OF EFFICIENCY LEVEL OF SOME SOYBEAN VARIETIES' PLANTING METHOD IN THE LOWLAND AREAS
}

\author{
Arifin Z.*, Saeri M. \\ Assessment Institute for Agricultural Technology, East Java, Indonesia \\ *E-mail: arifin bptpjatim@yahoo.co.id
}

\begin{abstract}
This study aims to determine the effect of planting method some soybean varieties in the lowland on growth and yield of soybean. The event was held in the Mojokerto and Lamongan District, east Java Indonesia the in dry season of 2014. Experiments in randomized factorial block design with 12 treatments and repeated 3 times, that is a factor I (3 varieties), that is: Anjasmoro; Sinabung and Kaba, and factor II (4 ways of planting): planting spread; planting spread + mulch; planting drill; and planting drill+mulch. Spacious plot of $4 \mathrm{~m} \times 3 \mathrm{~m}$ with a drill spacing of $40 \mathrm{~cm} \times 15 \mathrm{~cm}$ (seed as much as $40 \mathrm{~kg} / \mathrm{ha}$, and method to plant spread (seed as much as $80 \mathrm{~kg} / \mathrm{ha}$ ). Mulch of straw $5 \mathrm{t} / \mathrm{ha}$ given evenly, the amount of fertilizer given based on recommendation from AIAT East Java. Results of the study in both locations showed that Kaba variety ( $2.13 \mathrm{t} / \mathrm{ha})$, was the highest yield in Mojokerto and the Sinabung variety $(2.18 \mathrm{t}$ / ha) was the highest yield in Lamongan. Then the way of planting drill + mulch $5 \mathrm{t} / \mathrm{ha}$ in Mojokereto and Lamongan together gives the highest result that are 2,11 ton/ha and 2,17 t/ha. Economic Analysis Soybean cultivation in lowland with Kaba (Mojokerto) varieties and Sinabung (Lamongan) by planting drill method with mulch was given most economically evisien, because R/C Ratio achieved respectively highest are 3,38 and 3,07 than others.
\end{abstract}

\section{KEY WORDS}

Method of planting, varieties, soybean, lowland, Lamongan, Mojokerto.

Soybean production of national can be increased through increasing productivity and expansion of planting area. The productivity of soybean at the farmer level is still low, ie an average of $1.3 \mathrm{t} / \mathrm{ha}$ with a range of 0.6-2.0 t/ha, while the potential yield can reach $3.0 \mathrm{t} / \mathrm{ha}$. This enormous productivity gap provides an opportunity for increased production through increased productivity at the farm level [1].; [2]. According, low soybean production in addition to being influenced by low productivity at farm level, as well as local market has not been very attractive to farmers and the difficulty of developing soybean agribusiness due to limited soybean farming, and lack of adequate infrastructure and lack of seeds the good one. Increased productivity of soybeans can be achieved with farms that employ location specific soybean production technologies including using quality new superior varieties seeds and specific location fertilization, land preparation, maintenance and plant protection and postharvest [3].

One of the determinants of the success of soybean farming is the provision of quality seeds from superior varieties and its supply following the precise six patterns of exact varieties, quality, time, quantity, place and price but this pattern is never fully achieved. Superior varieties greatly determine the level of productivity of crops and are technological components that are relatively easy to adopt farmers [4].; [5]. According to increasing soybean productivity can be achieved when applying appropriate technology (new superior variety and land, water, and plant disturbing organism) for each agroecosystem [6]. In Lowland agroecosystem, soybean is usually grown on DS. I planted after the first rice harvest or on DS II planted after the second rice harvest [7]. According to [8].; [9]. The success of technological package was determined by the application of technology approved by farmers and authors/counselors.

Common obstacles to soybean development in lowland rice are the saturation of the water at the beginning of the cropping season which is bad for the germination of soybean seeds, the solid soil structure will hamper the development of plant roots [10]. Soybean 
variety selection should be based on maturity, yield potential, lodging, drought tolerance, and resistance to pests and diseases. The maturity period should be the first consideration when choosing a variety suited to your geographical zone. Therefore, on the solid soil structure it is necessary to consider proper land management. In general, farmers plant soybeans in lowland rice without preceding soil tillage, to avoid the delay of planting time that can reduce soybean yield. [11] According, treatment of soil tillage before planting in lowland does not increase yield compared with no tillage. Unprocessed soils are usually followed by straw cutting at the soil surface and used as mulch for soybean crops $\left[4^{+}\right],\left[3^{+}\right]$, so mulch serves to suppress weed growth, seed fly attack and reduce evapotranspiration and increase chances results.

Soybean produces well over a wide range of planting dates, if moisture is available [12]. Soybean in lowland is planted drill or spread. Planting in a dispersed way is taken for two reasons, namely: (a) labor shortage, by planting the spread of planting power will be much less, and (b) to optimize the use of soil moisture, at harvest time the soil is still muddy cannot be planting drill, if waiting for the condition of the soil can planting drill means there will be loss of moisture, so that the soybean seeds are planted on a scattered land is still muddy $\left[4^{++}\right],\left[3^{++}\right]$. By way of planting spreads resulted in differences in planting time is faster and the need for more seeds than how to plant drill. In addition, planting scattering methods will make it difficult in plant maintenance such as fertilizing, weeding, spraying and harvesting.

This study aims to determine the effect of planting method and mulch usage of some soybean varieties in lowland on the growth, yield and efficiency level of soybeans.

\section{MATERIALS AND METHODS OF RESEARCH}

The research location of planting method of soybean varieties is located in lowland of Sidorejo Village, Sugio Sub-district, Lamongan District and Paterongan Village, Bangsal Subdistrict, Mojokerto District, at dry season of 2014. Experiments used randomized factorial block design with 12 treatments and repeated 3 times, ie factor I (3 varieties ): a) Anjasmoro, b) Sinabung, and c) Kaba, as well as factor II (4 method of planting): a) planting spread, b) planting spread + mulch, c) planting drill, and d) planting drill + mulch. Size of plot of $4 \mathrm{~m} \times 3$ $\mathrm{m}$ with a drill spacing of $40 \mathrm{~cm} \times 15 \mathrm{~cm}$ (seed as much as $40 \mathrm{~kg} / \mathrm{ha}$, 2 seeds per hole), and method to plant spread (seed as much as $80 \mathrm{~kg} / \mathrm{ha}$ ). Rice straw mulch as much as $5 \mathrm{t} / \mathrm{ha}$ are given by way of evenly distributed, while the dose of fertilizer was $50 \mathrm{~kg}$ Urea/ha $+75 \mathrm{~kg} \mathrm{SP}$ $36 / \mathrm{ha}+75 \mathrm{~kg} \mathrm{KCl} / \mathrm{ha}+1$ ton of organic fertilizer/ha. The method of fertilization of organic fertilizer $1 \mathrm{t} / \mathrm{ha}$ and all doses of inorganic fertilizers is given by planting drill about $5 \mathrm{~cm}$ in addition to the line of plants, together with the time of planting soybeans. who states that wet land has adequate nutrient, and thus the yield is quite promising despite less addition of fertilizers [13]. The time of weeding of soybean plants was done at age 30 DAP and 60 DAP.

Plant observations included: plant height, number of branches per plant, number of leaves per plant, number of pods per plant, weight of 100 dry seeds and dry seed yield (t/ha). Analyze data using ANOVA followed by Duncan multiple range test (DMRT 5\%) [14]. Analysis of soybean farming was done to determine the feasibility of soybean farming using R/C Ratio. [15].;[16].; [17].; [18]. Mathematically feasibility of soybean farming by calculating $\mathrm{R} / \mathrm{C}$, that is as follows:

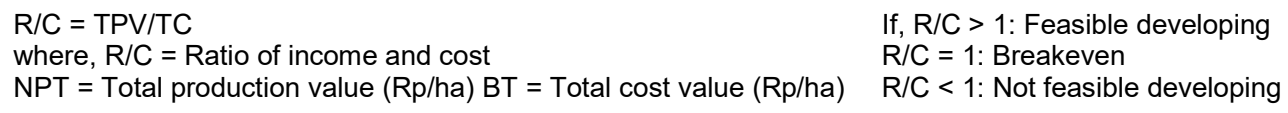

If, $\mathrm{R} / \mathrm{C}>1$ : Feasible developing

$\mathrm{R} / \mathrm{C}=1:$ Breakeven

$\mathrm{R} / \mathrm{C}<1$ : Not feasible developing

\section{RESULTS AND DISCUSSION}

The analysis of variance showed that the interaction between the treatment of several varieties and the method of planting in lowland that had real effect in Mojokerto District was found to 1 observed variables, namely: number of branches per plant age 40 DAP, while in Lamongan District found 2 variables that is on the number of leaves per plant age 40 DAP 
and 70 DAP. The treatment of varieties in Mojokerto District had significant effect on 5 observed variables: height of soybean plant age 40 DAP and 70 DAP, number of leaves per plant age 40 DAP and 70 DAP, and number of branches per plant age 40 DAP, while in Lamongan District 5 varieties of varieties are significantly different, namely: high soybean plants age 40 DAP and 70 DAP, number of leaves per plant age 40 DAP and 70 DAP, and number of branches per plant age 70 DAP. For the treatment of planting method in Mojokerto District have significant effect on 2 observed variables, namely: the number of leaves per plant age 70 DAP and weight of 100 seeds, whereas in Lamongan District there are 6 variables that are significantly different, ie height of soybean plant age 40 DAP and 70 DAP, number of leaves per plant age 40 DAP and 70 DAP, weight of 100 seeds and seed yield (Table 1).

Table 1 - Recapitulation of various method of planting some of soybean varieties on growth and yield of soybean in Mojokerto District and Lamongan District, DS I 2014

\begin{tabular}{|l|c|c|c|c|c|c|}
\hline \multirow{2}{*}{ Variable } & \multicolumn{2}{c|}{$\begin{array}{c}\text { Varieties } \\
\text { (V) }\end{array}$} & \multicolumn{2}{c|}{$\begin{array}{c}\text { Planting method } \\
(\mathrm{P})\end{array}$} & \multicolumn{2}{c|}{$\begin{array}{c}\text { Interaction } \\
(\mathrm{V} \times \mathrm{P})\end{array}$} \\
\cline { 2 - 7 } & Mjkerto & Lmngan & Mjkerto & Lmngan & Mjkerto & Lmngan \\
\hline High soybean plant age 40 DAP & ${ }^{*}$ & ${ }^{*}$ & $\mathrm{~ns}$ & ${ }^{* *}$ & $\mathrm{~ns}$ & $\mathrm{~ns}$ \\
\hline Number of branches per plant age 40 DAP & ${ }^{*}$ & $\mathrm{~ns}$ & $\mathrm{~ns}$ & $\mathrm{~ns}$ & ${ }^{* *}$ & $\mathrm{~ns}$ \\
\hline Number of leaves per plant age 40 DAP & ${ }^{*}$ & ${ }^{*}$ & $\mathrm{~ns}$ & ${ }^{*}$ & $\mathrm{~ns}$ & ${ }^{*}$ \\
\hline High soybean plant age 70 DAP & ${ }^{*}$ & ${ }^{*}$ & $\mathrm{~ns}$ & ${ }^{* *}$ & $\mathrm{~ns}$ & $\mathrm{~ns}$ \\
\hline Number of branches per plant age 70 DAP & $\mathrm{ns}$ & ${ }^{* *}$ & $\mathrm{~ns}$ & $\mathrm{~ns}$ & $\mathrm{~ns}$ & $\mathrm{~ns}$ \\
\hline Number of leaves per plant age 70 DAP & ${ }^{*}$ & ${ }^{*}$ & ${ }^{* *}$ & ${ }^{*}$ & $\mathrm{~ns}$ & ${ }^{*}$ \\
\hline Number of pods per plant & $\mathrm{ns}$ & $\mathrm{ns}$ & $\mathrm{ns}$ & $\mathrm{ns}$ & $\mathrm{ns}$ & $\mathrm{ns}$ \\
\hline Weight of 100 dry seeds (g) & $\mathrm{ns}$ & $\mathrm{ns}$ & ${ }^{*}$ & ${ }^{*}$ & $\mathrm{~ns}$ & $\mathrm{~ns}$ \\
\hline Seed yield (t/ha) & $\mathrm{ns}$ & $\mathrm{ns}$ & $\mathrm{ns}$ & ${ }^{*}$ & $\mathrm{~ns}$ & $\mathrm{~ns}$ \\
\hline
\end{tabular}

Description: ** and * are each significantly different at the error rate of $1 \%$ and $5 \%$; ns = no significant.

Effect of Variety and Planting Method Interaction. The interaction of the treatment of varieties with planting method in Mojokerto District with the number of branches per plant at the age of 40 DAP highest was found in the use of Anjasmoro varieties by planting spread + mulch $5 \mathrm{t} / \mathrm{ha}$ ( 0.90 branch) or by planting drill ( 0.90 branch), as well as Kaba varieties by panting drill (89 branches), whereas in Lamongan District there is interaction between varieties and planting method to the highest number of leaves per plant at 40 DAP observation using Kaba varieties by planting spread + mulch $5 \mathrm{t} /$ ha (12, 22 leaves), while the observation of the number of leaves per plant age 70 DAP did not show a real interaction between the use of varieties and planting method of soybeans. The interaction of the planting method treatment of several varieties of soybean showed that the diversity of genetic factors of some soybean varieties had the response of planting method to the number of leaves and number of branches per plant. Argomulyo Variety has better prospect becuse it has big size of seed with uniform color of yellow [19].

Effect of Variety. High plant of soybean in lowland the highest in Mojokerto District at 40 DAP observation on Anjasmoro variety, and 70 DAP observation was found in Sinabung variety, whereas in Lamongan District, plant height at 40 DAP did not show significant differences between varieties, and observation age 70 DAP found height plant of highest on Sinabung variety.

The soybean branches number of highest at age 40 DAP in Mojokerto District was found in interaction of Anjasmoro varieties by planting spread + mulch $5 \mathrm{t} / \mathrm{ha}$ ( 0.90 branches) or planting drill method ( 0.90 branches) and Kaba varieties by planting drill ( 0,89 branches), whereas in Lamongan District, the largest number of soybean branches is produced by Kaba and Sinabung varieties. The largest number of soybean branches at the age of 70 DAP in Mojokerto District is produced by Sinabung of 3.03 branches, while in Lamongan District, the most branches are found in Sinabung and Kaba varieties was each of 2.86 branches and 2.83 branches.

The highest number of leaves per plant at the age of 40 DAP in Mojokerto District produced 11.13 leaf varieties of Anjasmoro, while in Lamongan District found in interaction of 
Kaba varieties by planting spread + mulch $5 \mathrm{t} / \mathrm{ha}$ of 12.22 leaves. The highest number of leaves per plant at age 70 DAP in Mojokerto District and Lamongan District of some varieties and planting methods did not show significant differences (Table 2).

Table 2 - Effect of planting method on plant height, number of branches, and number of leaves of three soybean varieties in lowland of Mojokerto District and Lamongan District, DS I 2014

\begin{tabular}{|c|c|c|c|c|c|c|c|c|}
\hline \multirow{2}{*}{$\begin{array}{c}\text { Varieties/ } \\
\text { Planting Method } \\
\end{array}$} & \multicolumn{4}{|c|}{ Mojokerto } & \multicolumn{4}{|c|}{ Lamongan } \\
\hline & Anjasmoro & Sinabung & Kaba & Rataan & Anjasmoro & Sinabung & Kaba & Rataan \\
\hline & \multicolumn{8}{|c|}{ High plant age 40 DAP $(\mathrm{cm})$} \\
\hline Spread & 42,56 & 43,76 & 42,44 & $42,92 b$ & 42,34 & 42,11 & 41,22 & $41,89 \mathrm{~b}$ \\
\hline Spread+mulch & 53,56 & 55,33 & 49,89 & $52,93 a$ & 42,22 & 44,22 & 44,89 & $43,78 b$ \\
\hline Drill & 49,56 & 46,22 & 44,11 & $46,63 b$ & 43,22 & 41,33 & 44,56 & $43,04 b$ \\
\hline Drill+ mulch & 47,44 & 44,67 & 41,89 & $44,67 b$ & 48,89 & 44,89 & 49,22 & $47,67 a$ \\
\hline \multirow[t]{2}{*}{ Average } & $48,28 a$ & $47,49 a b$ & $44,58 b$ & 46,79 & $44,17 a$ & $43,14 a$ & $44,97 a$ & 44,09 \\
\hline & \multicolumn{8}{|c|}{ Number of branches per plant age $40 \mathrm{DAP}$} \\
\hline Spread & $0,10 c$ & $0,23 b c$ & $0,40 a b c$ & 0,13 & 2,00 & 2,33 & 3,00 & $2,44 b$ \\
\hline Spread+mulch & $0,90 a$ & $0,57 a b c$ & $0,43 a b c$ & 0,63 & 2,87 & 3,56 & 2,89 & $3,10 a$ \\
\hline Drill & $0,90 a$ & $0,78 a b$ & $0,89 a$ & 0,86 & 1,87 & 2,22 & 2,22 & $2,10 c$ \\
\hline Drill+ mulch & $0,77 a b$ & $0,67 a b c$ & $0,67 a b c$ & 0,70 & 2,00 & 2,00 & 2,44 & $2,15 c$ \\
\hline \multirow[t]{2}{*}{ Average } & 0,67 & 0,56 & 0,51 & 0,58 & $2,18 b$ & $2,53 a$ & $2,64 a$ & 2,45 \\
\hline & \multicolumn{8}{|c|}{ Number of leaves per plant age 40 DAP } \\
\hline Spread & 9,31 & 9,11 & 9,67 & $9,36 \mathrm{c}$ & $10,78 b c$ & $11,78 a b c$ & $11,11 \mathrm{abc}$ & 11,22 \\
\hline Spread+mulch & 11,21 & 10,00 & 10,68 & $10,63 b$ & $10,78 \mathrm{bc}$ & $11,78 a b c$ & $12,22 \mathrm{a}$ & 11,59 \\
\hline Drill & 11,43 & 11,33 & 12,56 & $11,77 a$ & $10,67 c$ & $11,44 a b c$ & $11,00 \mathrm{abc}$ & 11,04 \\
\hline Drill+ mulch & 12,56 & 11,56 & 11,34 & $11,82 a$ & $11,00 \mathrm{abc}$ & $12,11 \mathrm{ab}$ & $10,89 \mathrm{c}$ & 11,33 \\
\hline \multirow[t]{2}{*}{ Average } & $11,13 a$ & $10,50 \mathrm{~b}$ & $11,06 a b$ & 10,90 & 10,81 & 11,78 & 11,31 & 11,30 \\
\hline & \multicolumn{8}{|c|}{ High plant age 70 DAP $(\mathrm{cm})$} \\
\hline Spread & 54,76 & 60,43 & 60,89 & $58,69 b$ & 46,22 & 47,78 & 45,33 & $46,44 b$ \\
\hline Spread+mulch & 63,89 & 68,00 & 67,67 & $66,52 a$ & 49,43 & 55,22 & 50,99 & $51,88 a$ \\
\hline Drill & 54,22 & 62,11 & 55,89 & $57,41 \mathrm{~b}$ & 51,78 & 57,11 & 46,44 & $51,78 a$ \\
\hline Drill+ mulch & 58,66 & 59,00 & 57,44 & $58,37 b$ & 54,34 & 58,44 & 52,67 & $55,15 a$ \\
\hline \multirow[t]{2}{*}{ Average } & $57,88 \mathrm{~b}$ & $62,39 a$ & $60,47 a b$ & 60,25 & $50,44 b$ & $54,64 a$ & $48,86 \mathrm{~b}$ & 51,31 \\
\hline & \multicolumn{8}{|c|}{ Number of branches per plant age 70 DAP } \\
\hline Spread & 2,11 & 2,89 & 2,33 & $2,44 b$ & 2,66 & 2,76 & 3,00 & $2,80 a$ \\
\hline Spread+mulch & 1,78 & 2,90 & 2,11 & $2,26 b$ & 2,00 & 3,67 & 2,77 & $2,81 a$ \\
\hline Drill & 2,44 & 3,11 & 3,11 & $2,89 a$ & 1,21 & 2,33 & 2,90 & $2,15 b$ \\
\hline Drill+ mulch & 2,78 & 3,23 & 3,11 & $3,04 a$ & 1,90 & 2,67 & 2,64 & $2,40 b$ \\
\hline \multirow[t]{2}{*}{ Average } & $2,28 \mathrm{c}$ & $3,03 a$ & $2,67 \mathrm{~b}$ & 2,66 & $1,94 b$ & $2,86 a$ & $2,83 a$ & 2,54 \\
\hline & \multicolumn{8}{|c|}{ Number of leaves per plant age 70 DAP } \\
\hline Spread & 11,11 & 11,67 & 12,02 & $11,60 \mathrm{~b}$ & $13,67 a$ & $13,22 a$ & $13,56 a$ & 13,48 \\
\hline Spread+mulch & 11,22 & 13,11 & 12,00 & $12,11 \mathrm{a}$ & $12,67 a$ & $13,78 a$ & $13,56 a$ & 13,33 \\
\hline Drill & 11,22 & 10,89 & 11,22 & $11,11 \mathrm{~b}$ & $13,00 a$ & $12,67 a$ & $13,56 a$ & 13,07 \\
\hline Drill+ mulch & 12,11 & 10,67 & 11,46 & $11,41 b$ & $13,78 a$ & $13,00 a$ & $13,67 a$ & 13,48 \\
\hline Average & $11,42 a$ & $11,58 a$ & $11,68 a$ & 11,56 & 13,28 & 13,17 & 13,58 & 13,34 \\
\hline
\end{tabular}

The numbers followed by the same letter on the same column and row do not differ significantly on the DMR test of 5\%.

The highest number of pods per plant in Mojokerto District and Lamongan District was found in the Anjasmoro varieties of 103.03 pods and 106.37 pods, while the highest 100 seeds in Mojokerto District and Lamongan District were found in Anjasmoro varieties, each weighing $14.02 \mathrm{~g}$ and $11.40 \mathrm{~g}$ (Table 3).

The highest yield of soybean seeds in Mojokerto District was found using Kaba varieties of $2.13 \mathrm{t} / \mathrm{ha}$, while in Lamongan District, soybean crop yielding the highest seeds was found in Sinabung varieties of 2.18 t/ha (Figure 1). Soybean of Kaba and Sinabung varieties of medium seeds have the adaptability to grow better when planted in lowland after rice than Anjasmoro varieties of large seeds. $\left[4^{+++}\right]$. According, superior varieties greatly determine the level of productivity of crops and is a technology component that is relatively easy to adopt farmers.

Effect of Planting Method. The highest planting height of soybean in Mojokerto District was observed at age 40 DAP $(52.93 \mathrm{~cm})$ and age 70 hst $(66.52 \mathrm{~cm})$ was encountered with planting method + mulch $5 \mathrm{t} / \mathrm{ha}(52.93 \mathrm{~cm})$, whereas in Lamongan District, the highest plant 
height at observation 40 DAP was found by planting drill + mulching $5 \mathrm{t} / \mathrm{ha}(47.67 \mathrm{~cm})$ and observation age 70 DAP was encountered with planting spread + mulching 5 t/ha $(51.88 \mathrm{~cm})$ or planting drill $(51.78 \mathrm{~cm})$ or planting drill + mulch $5 \mathrm{t} / \mathrm{ha}(55.15 \mathrm{~cm})$.

Table 3 - Effect of planting method to number of pods, weight of 100 seeds and yield of three varieties of soybean in lowland of Mojokerto and Lamongan District, DS I 2014

\begin{tabular}{|c|c|c|c|c|c|c|c|c|}
\hline \multirow{3}{*}{$\begin{array}{c}\text { Varieties/ } \\
\text { Planting Method }\end{array}$} & \multicolumn{4}{|c|}{ Mojokerto } & \multicolumn{4}{|c|}{ Lamongan } \\
\hline & Anjasmoro & Sinabung & Kaba & Rataan & Anjasmoro & Sinabung & Kaba & Rataan \\
\hline & \multicolumn{8}{|c|}{ Number of pods per plant } \\
\hline Spread & 89,32 & 81,77 & 91,77 & $87,62 d$ & 105,56 & 106,43 & 100,66 & $104,21 b$ \\
\hline Spread+mulch & 111,53 & 93,57 & 72,89 & $92,66 c$ & 136,56 & 100,10 & 103,67 & $113,44 a$ \\
\hline Drill & 87,69 & 104,10 & 99,33 & $97,04 b$ & 90,47 & 79,11 & 96,56 & $88,71 \mathrm{c}$ \\
\hline Drill+ mulch & 123,56 & 84,42 & 95,02 & $101,00 a$ & 92,90 & 83,67 & 80,33 & $85,63 c$ \\
\hline \multirow[t]{2}{*}{ Average } & $103,03 a$ & $90,96 b$ & $89,75 b$ & 94,58 & $106,37 a$ & $92,33 b$ & $95,30 \mathrm{~b}$ & 98,00 \\
\hline & \multicolumn{8}{|c|}{ Weight of 100 dry seeds $(\mathrm{g})$} \\
\hline Spread & 13,90 & 10,56 & 10,65 & $11,70 a$ & 11,62 & 8,42 & 8,96 & $9,66 a$ \\
\hline Spread+mulch & 14,17 & 10,59 & 10,37 & $11,71 \mathrm{a}$ & 11,42 & 8,45 & 8,55 & $9,47 a$ \\
\hline Drill & 14,45 & 10,68 & 10,54 & $11,89 a$ & 11,06 & 8,13 & 8,12 & $9,10 a$ \\
\hline Drill+ mulch & 13,57 & 11,06 & 10,40 & $11,68 a$ & 11,51 & 8,36 & 8,35 & $9,41 a$ \\
\hline \multirow[t]{2}{*}{ Average } & $14,02 a$ & $10,72 b$ & $10,49 b$ & 11,75 & $11,40 a$ & $8,34 b$ & $8,49 \mathrm{~b}$ & 9,41 \\
\hline & \multicolumn{8}{|c|}{ Yield seed (t/ha) } \\
\hline Spread & 1,16 & 1,62 & 2,05 & $1,61 \mathrm{c}$ & 1,51 & 1,94 & 2,02 & $1,82 a$ \\
\hline Spread+mulch & 1,75 & 2,27 & 2,22 & $2,08 a$ & 1,75 & 2,21 & 2,27 & $2,08 a$ \\
\hline Drill & 1,32 & 2,09 & 1,92 & $1,78 b$ & 1,52 & 2,21 & 2,02 & $1,92 a$ \\
\hline Drill+ mulch & 1,62 & 2,33 & 2,35 & $2,11 a$ & 1,98 & 2,34 & 2,19 & $2,17 a$ \\
\hline Average & $1,46 b$ & $2,08 a$ & $2,13 a$ & 1,89 & $1,69 c$ & $2,18 a$ & $2,13 b$ & 2,00 \\
\hline
\end{tabular}

The numbers followed by the same letter on the same column and row do not differ significantly on the DMR test of 5\%.

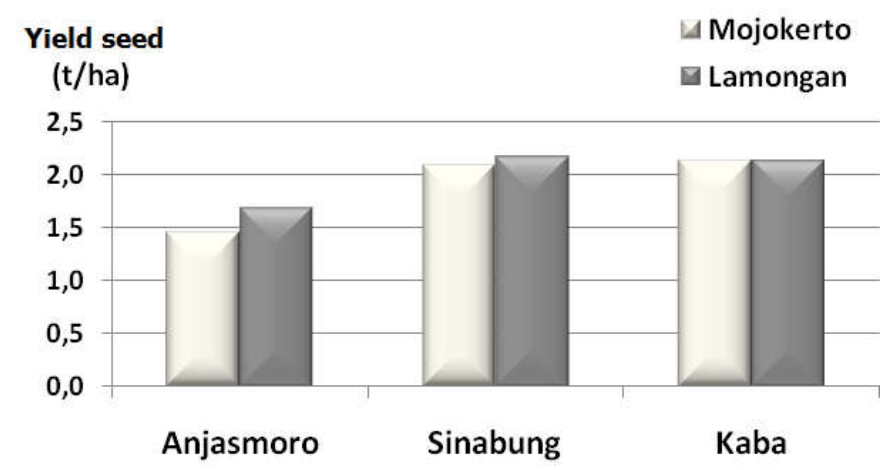

Figure 1 - The yield of soybean seed from varieties Anjasmoro, Sinabung and Kaba

The highest number of branches per plant of soybean in Mojokerto District at observation 70 DAP was found by planting drill + mulch 5 t/ha $(3,04$ branches) and planting drill (2.89 branches), while in Lamongan District, 40 DAP (3.10 branches) and 70 DAP (2.81 branches) were found by planting spread + mulch $5 \mathrm{t} / \mathrm{ha}$. The number of leaf per plant in Mojokerto District at observation 40 DAP was found on planting drill (11.77 leaves) or planting drill + mulch 5 t/ha (11.82 leaves), while observation age 70 DAP was found by planting spread + mulch 5 t/ha (12.11 leaves).

The highest number of pods per plant of soybean in Mojokerto District was found in the planting drill + mulch 5 t/ha as much 101 pods, while in Lamongan District the highest number of pods on planting spread was 113,44 pods. The weight of 100 seeds of soybean from several planting method in Mojokerto District and Lamongan District showed no significant difference.

The yield seeds of soybean in Mojokerto District and Lamongan District resulted in the highest weight by planting drill + mulch $5 \mathrm{t} /$ ha each $2.11 \mathrm{t} /$ ha and $2.17 \mathrm{t} /$ ha (Figure 2). 
Table 4 - Analysis of farming of some varieties of soybean with various planting method in lowland, DS I 2014, Mojokerto District

\begin{tabular}{|c|c|c|c|c|c|c|c|c|c|c|c|c|c|}
\hline No. & Activity & $\begin{array}{c}\text { Anjas+ } \\
\text { spr }\end{array}$ & $\begin{array}{c}\text { Anjas+ } \\
\text { spr+mlc }\end{array}$ & $\begin{array}{c}\text { Anjas+ } \\
\text { drill }\end{array}$ & $\begin{array}{c}\text { Anjas+ } \\
\text { drill+mlc }\end{array}$ & Snbung+sp & $\begin{array}{r}\text { Snbung+ } \\
\text { spr+mlc }\end{array}$ & Snbung+drill & $\begin{array}{l}\text { Snbung+ } \\
\text { drill+mlc }\end{array}$ & $\begin{array}{c}\text { Kaba+ } \\
\text { spr }\end{array}$ & $\begin{array}{c}\text { Kaba+ } \\
\text { spr+mlc }\end{array}$ & $\begin{array}{c}\text { Kaba+ } \\
\text { drill }\end{array}$ & $\begin{array}{c}\text { Kaba+ } \\
\text { drill+mlc }\end{array}$ \\
\hline \multicolumn{14}{|c|}{$(x \operatorname{IRD} .000)$} \\
\hline $\mathrm{I}$ & Labor (DW) & & & & & & & & & & & & \\
\hline 1. & Channel & 240 & 240 & 240 & 240 & 240 & 240 & 240 & 240 & 240 & 240 & 240 & 240 \\
\hline \multirow{2}{*}{2.} & Cropping : spead & 140 & 140 & & & 140 & 140 & & & 140 & 140 & & \\
\hline & drill & & & 550 & 550 & & & 550 & 550 & & & 550 & 550 \\
\hline 3. & Cut straw & 360 & 360 & 360 & 360 & 360 & 360 & 360 & 360 & 360 & 360 & 360 & 360 \\
\hline 4. & Fertilization & 240 & 240 & 240 & 240 & 240 & 240 & 240 & 240 & 240 & 240 & 240 & 240 \\
\hline 5. & Spraying & 120 & 120 & 120 & 120 & 120 & 120 & 120 & 120 & 120 & 120 & 120 & 120 \\
\hline 6. & Weeding & 400 & 400 & 400 & 400 & 400 & 400 & 400 & 400 & 400 & 400 & 400 & 400 \\
\hline 7. & Harvest & 580 & 580 & 580 & 580 & 580 & 580 & 580 & 580 & 580 & 580 & 580 & 580 \\
\hline 8. & Drying & 200 & 200 & 200 & 200 & 200 & 200 & 200 & 200 & 200 & 200 & 200 & 200 \\
\hline 9. & Threshing & 240 & 240 & 240 & 240 & 240 & 240 & 240 & 240 & 240 & 240 & 240 & 240 \\
\hline II & Means prod. (kg; lt) & & & & & & & & & & & & \\
\hline 1. & Seed $(\mathrm{kg} / \mathrm{ha})$ & 960 & 960 & 600 & 600 & 960 & 960 & 600 & 600 & 960 & 960 & 600 & 600 \\
\hline \multirow{5}{*}{2.} & Fertilizer (kg/ha): & & & & & & & & & & & & \\
\hline & Urea & 90 & 90 & 90 & 90 & 90 & 90 & 90 & 90 & 90 & 90 & 90 & 90 \\
\hline & SP-36 & 150 & 150 & 150 & 150 & 150 & 150 & 150 & 150 & 150 & 150 & 150 & 150 \\
\hline & $\mathrm{KCl}$ & 450 & 450 & 450 & 450 & 450 & 450 & 450 & 450 & 450 & 450 & 450 & 450 \\
\hline & Petroganik & 500 & 500 & 500 & 500 & 500 & 500 & 500 & 500 & 500 & 500 & 500 & 500 \\
\hline 3. & Pesticide (It/ha) & 152 & 152 & 152 & 152 & 152 & 152 & 152 & 152 & 152 & 152 & 152 & 152 \\
\hline III & Cost of Prod. (Rp/ha) & 4.822 & 4.822 & 4.872 & 4.872 & 4.822 & 4.822 & 4.872 & 4.872 & 4.822 & 4.822 & 4.872 & 4.872 \\
\hline \multirow[t]{2}{*}{ IV } & Seed yied (kg/ha) & 1.160 & 1.750 & 1.320 & 1.620 & 1.620 & 2.270 & 2.090 & 2.330 & 2.050 & 2.220 & 1.900 & 2.350 \\
\hline & Revenue (Rp/ha) & 8.120 & 12.250 & 9.240 & 11.340 & 11.340 & 15.890 & 14.630 & 16.310 & 14.350 & 15.540 & 13.300 & 16.450 \\
\hline V & profit (Rp/ha) & 3.298 & 7.428 & 4.368 & 6.468 & 6.518 & 11.068 & 9.758 & 11.438 & 9.528 & 10.718 & 8.428 & 11.578 \\
\hline$V I$ & $R / C$ & 1,68 & 2,54 & 1,90 & 2,33 & 2,35 & 3,30 & 3,00 & 3,35 & 2,98 & 3,22 & 2,73 & 3,38 \\
\hline
\end{tabular}

Description of price: seeds $=$ Rp. 12,000/kg; consumption $=$ Rp. 7,000/kg; Urea $=$ Rp. 1,800/kg; SP-36 = Rp. 2,000/kg; KCl=Rp. 6,000/kg; Petroganik = Rp. 500/kg 
RJOAS, 11(71), November 2017

Table 5 - Analysis of farming of some varieties of soybean with various planting method in lowland, DS I 2014, Lamongan District

\begin{tabular}{|c|c|c|c|c|c|c|c|c|c|c|c|c|c|}
\hline No. & Activity & $\begin{array}{c}\text { Anjas }+ \\
\text { spr }\end{array}$ & $\begin{array}{c}\text { Anjas+ } \\
\text { spr+mlc }\end{array}$ & $\begin{array}{c}\text { Anjas+ } \\
\text { drill }\end{array}$ & $\begin{array}{c}\text { Anjas+ } \\
\text { drill+mlc }\end{array}$ & $\begin{array}{c}\text { Snbung+ } \\
\text { spr }\end{array}$ & $\begin{array}{c}\text { Snbung+ } \\
\text { spr+mlc }\end{array}$ & $\begin{array}{c}\text { Snbung+ } \\
\text { drill }\end{array}$ & $\begin{array}{l}\text { Snbung+ } \\
\text { drill+mlc }\end{array}$ & $\begin{array}{c}\text { Kaba+ } \\
\text { spr }\end{array}$ & $\begin{array}{c}\text { Kaba+ } \\
\text { spr+mlc }\end{array}$ & $\begin{array}{c}\text { Kaba+ } \\
\text { drill }\end{array}$ & $\begin{array}{c}\text { Kaba+ } \\
\text { drill+mlc }\end{array}$ \\
\hline \multicolumn{14}{|c|}{ (x IRD.000) } \\
\hline $\mathrm{I}$ & Labor (DW) & & & & & & & & & & & & \\
\hline 1. & Channel & 300 & 300 & 300 & 300 & 300 & 300 & 300 & 300 & 300 & 300 & 300 & 300 \\
\hline \multirow{2}{*}{2.} & Cropping : spead & 170 & 170 & & & 170 & 170 & & & 170 & 170 & & \\
\hline & drill & & & 550 & 550 & & & 550 & 550 & & & 550 & 550 \\
\hline 3. & Cut straw & 400 & 400 & 400 & 400 & 400 & 400 & 400 & 400 & 400 & 400 & 400 & 400 \\
\hline 4. & Fertilization & 230 & 230 & 230 & 230 & 230 & 230 & 230 & 230 & 230 & 230 & 230 & 230 \\
\hline 5. & Spraying & 120 & 120 & 120 & 120 & 120 & 120 & 120 & 120 & 120 & 120 & 120 & 120 \\
\hline 6. & Weeding & 640 & 640 & 640 & 640 & 640 & 640 & 640 & 640 & 640 & 640 & 640 & 640 \\
\hline 7. & Harvest & 740 & 740 & 740 & 740 & 740 & 740 & 740 & 740 & 740 & 740 & 740 & 740 \\
\hline 8. & Drying & 200 & 200 & 200 & 200 & 200 & 200 & 200 & 200 & 200 & 200 & 200 & 200 \\
\hline 9. & Threshing & 340 & 340 & 340 & 340 & 340 & 340 & 340 & 340 & 340 & 340 & 340 & 340 \\
\hline II & Means prod. (kg; lt) & & & & & & & & & & & & \\
\hline 1. & Seed (kg/ha) & 960 & 960 & 600 & 600 & 960 & 960 & 600 & 600 & 960 & 960 & 600 & 600 \\
\hline \multirow{5}{*}{2.} & Fertilizer (kg/ha): & & & & & & & & & & & & \\
\hline & Urea & 90 & 90 & 90 & 90 & 90 & 90 & 90 & 90 & 90 & 90 & 90 & 90 \\
\hline & SP-36 & 150 & 150 & 150 & 150 & 150 & 150 & 150 & 150 & 150 & 150 & 150 & 150 \\
\hline & $\mathrm{KCl}$ & 450 & 450 & 450 & 450 & 450 & 450 & 450 & 450 & 450 & 450 & 450 & 450 \\
\hline & Petroganik & 500 & 500 & 500 & 500 & 500 & 500 & 500 & 500 & 500 & 500 & 500 & 500 \\
\hline 3. & Pesticide (It/ha) & 185 & 185 & 185 & 185 & 185 & 185 & 185 & 185 & 185 & 185 & 185 & 185 \\
\hline III & Cost of Prod. (Rp/ha) & 5.475 & 5.475 & 5.495 & 5.495 & 5.475 & 5.475 & 5.495 & 5.495 & 5.475 & 5.475 & 5.495 & 5.495 \\
\hline \multirow[t]{2}{*}{$I V$} & Seed yied (kg/ha) & 1.510 & 1.750 & 1.520 & 1.980 & 1.940 & 2.210 & 2.210 & 2.340 & 2.020 & 2.270 & 2.020 & 2.190 \\
\hline & Revenue (Rp/ha) & 10.570 & 12.250 & 10.640 & 13.860 & 13.580 & 15.470 & 15.470 & 16.380 & 14.140 & 15.890 & 14.140 & 15.330 \\
\hline$V$ & profit (Rp/ha) & 5.095 & 6.775 & 5.145 & 8.365 & 8.105 & 9.995 & 9.975 & 11.045 & 8.665 & 10.415 & 8.645 & 9.835 \\
\hline VI & $R / C$ & 1,93 & 2,24 & 1,94 & 2,52 & 2,48 & 2,83 & 2,82 & 3,07 & 2,58 & 2,90 & 2,57 & 2,79 \\
\hline
\end{tabular}

Description of price: seeds $=$ Rp. 12,000/kg; consumption = Rp. 7,000/kg; Urea = Rp. 1,800/kg; SP-36 = Rp. 2,000/kg; KCl=Rp. 6,000/kg; Petroganik = Rp. 500/kg. 
Soybean is very sensitive to competition with weeds. In soybean cultivation of farmers in lowland is rarely done weeding, so weed control by using rice straw mulch of 5 t/ha can be recommended because it can suppress weed growth of about $55-65 \%\left[3^{+++}\right]$. In addition to helping suppress weeds, mulching on soybean crops can maintain soil moisture by suppressing the evaporation of ground water [20-21]. Added that the use of straw mulch with or without soil treatment can increase soybean yield, reduce weed growth and not decrease soil penetration than Oxadiazon herbicide application.

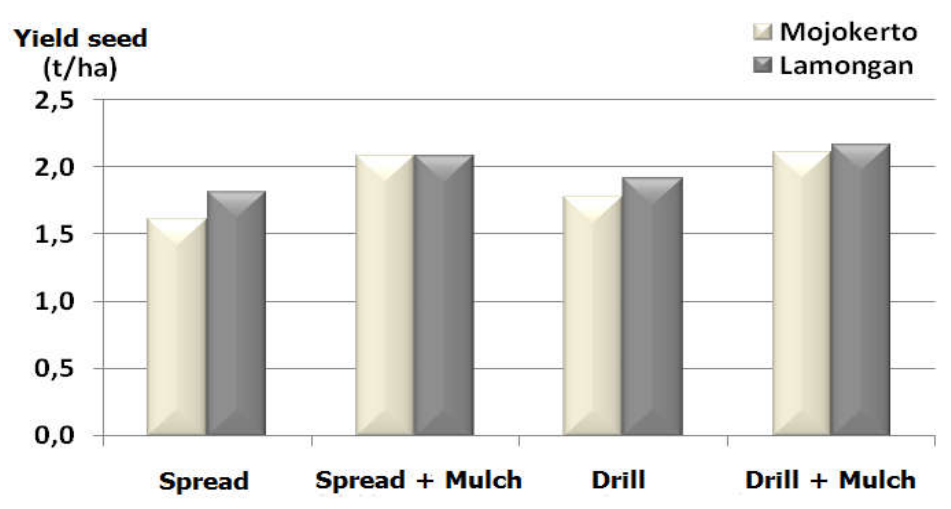

Figure 2 - Yield of soybean seeds from planting spread, planting spread + mulch, planting drill and planting drill + mulch

The types of weeds that develop on soybean crops in lowland include: narrow-leaved weeds/grasses: Tuton (Echinochloa colona), type of puzzles weed: Babawangan (Fimbristylis milacea), broadleaf weeds: Walik ope (Trianthema portulacastrum), etc.

Analysis of Soybean Farming. The results of soybean farming analysis showed that with soybean cultivation technology in Mojokerto District using Kaba varieties with planting drill and mulch obtained the highest R/C of 3.38 (Table 4), while in Lamongan District with using Sinabung varieties by planting drill and mulch obtained the highest R/C of 2.98 (Table 5 ), whereas, so the cultivation of soybeans in two locations is economically feasible. The high $\mathrm{R} / \mathrm{C}$ ratio in soybean cultivation by planting drill and mulch is influenced by the increase of seed yield and the low requirement and the cost of seed compared to the planting spread.

\section{CONCLUSION}

The interaction of varietal by planting soybean treatment only occurs on the number of branches and the number of leaves per plant.

The highest yield of soybean seeds in Mojokerto regency was found on the use of Kaba varieties (2.13 t/ha), while in Lamongan regency on Sinabung varieties (2.18 t/ha).

The yield of soybean seeds in Mojokerto regency and Lamongan regency resulted in the highest weight by planting drill + mulch $5 \mathrm{t} /$ ha respectively of $2.11 \mathrm{t} / \mathrm{ha}$ and $2.17 \mathrm{t} / \mathrm{ha}$.

Economic Analysis Soybean cultivation in lowland with Kaba (Mojokerto) varieties and Sinabung (Lamongan) by planting drill method + mulch was given most economically evisien, because R/C Ratio achieved respectively highest are 3,38 and 3,07 than others.

\section{REFERENCES}

1. Atman, 2009. Strategy to increase soybean production in Indonesia. Scientific Journal of Tambua, Vol. VIII, No. 1, January-April 2009: 39-45 p.

2. Kusbini, B.A. 2011. Problems, challenges and opportunities for achieving self-sufficiency in soybean. In Adie et al (eds.). Technological Innovation For Soybean Development Toward Self-Sufficiency. Proceedings of National Seminar on Research Results of Various Beans and Tubers. Center for Food Crops Research and Development. p: 11-16. 
3. Adisarwanto, T., Subandi and Sudaryono, 2007. Soybean production technology. In Sumarno et al. (Eds.). Soybean, Production and Development Technique. Center for Food Crops Research and Development. Agency for Agricultural Research and Development. p: 229-252.

4. Subandi, A. Harsono, and H. Kuntyastuti. 2007. Plantation area and soybean production system in Indonesia. In Sumarno et al. (Eds.). Soybean, Production and Development Technique. Center for Food Crops Research and Development. Agency for Agricultural Research and Development. p: 104-129.

5. Zakaria, A.K., 2010. Adoption Rate of Soybean Cultivation Technologies on Irrigated Wetland in Pasuruan, East Java. Center for Food Crops Research and Development. Journal of Food Crops Agriculture Research. 29 (3): 180-185.

6. Sudaryanto, T and D.K.S. Swastika, 2007. Soybean economy in Indonesia. In Sumarno et al. (Eds.). Soybean, Production and Development Technique. Center for Food Crops Research and Development. Agency for Agricultural Research and Development. p: 1-27

7. Puslitbangtan, 2010. Technical guide of soybean cultivation in various agro-ecosystem. Center for Food Crops Research and Development. 30p.

8. Suyamto dan Indrawati. 1992. Penelitian Pengembangan Budidaya Kedelai di Sumbawa. Makalah Balitan Malang no. 92.116

9. F.Kasijadi. 2000.Cooperative Farming Sebagai Pemanfaatan SumberdayaPertanian Lahan Sawah di Jawa Timur. Makalah diskusi panel. BPTP Karangploso.

10. Sudaryono, A. Taufiq and A. Wijanarko, 2007. Opportunity to increase soybean production in Indonesia. In Sumarno et al. (Eds.). Soybean, Production and Development Technique. Center for Food Crops Research and Development. Agency for Agricultural Research and Development. p: 130-167

11. Sumarno and A.G. Manshuri, 2007. Requirement of growing and production area of soybean in Indonesia. In Sumarno et al. (Eds.). Soybean, Production and Development Technique. Center for Food Crops Research and Development. Agency for Agricultural Research and Development. p: 74-103

12. Dugje, I.Y., L.O. Omoigui, F. Ekeleme, R. Bandyopadhyay, P. Lava Kumar, and A.Y. Kamara, (2009). Farmers' Guide to Soybean Production in Northern Nigeria.

13. Suyamto, 1999. Penelitian Lapang Pemupukan Kedelai Pada Jenis Tanah Aluvial, Grumosol, Latosol dan Planosol. Perbaikan Komponen Teknologi untuk Meningkatkan Produktivitas Tanaman Aneka Kacang dan Aneka Umbian. Edisi Khusus Balitkabi no.13

14. Gomez, A.K and A.A. Gomez. 1993. Statistical Procedures for Agricultural Research. 2nd Edition. Los Banos.

15. Soekartawi. 1993. Prinsip Dasar Ekonomi Pertanian Teori dan Aplikasinya. PT Raja Grafindo Persada, Jakarta.

16. 1995. Analisis Usahatani. UI-PRESS, Jakarta.

17. 2002. Farming analysis. University of Indonesia Press. p: 85-87

18. 2003. Teori Ekonomi Produksi. PT Raja Grafindo Persada, Jakarta.

19. Chamdi Ismail dan Gunawan Effendi. 1998. Pengkajian Teknik Produksi Varietas Unggul Kedelai. Prosiding Seminar Hasil Penelitian/Pengkajian BPTP Karangploso.

20. Ramakrishna, A., HM Tam, SP. Wani and TD Long, 2006. Effect of mulch on soil temperature, moisture, weed infestation and yield of groundnut in Northern Vietnam. Field Crops Res. 95: 115-125

21. Abdullah, S., 1999. Effect of soil management on weed growth and soybean yield after direct paddy rice crops. J. Agrotropika. 4 (2): 28-33. 